\title{
A practical tool for selecting microalgal species for biodiesel production
}

Cite as: J. Renewable Sustainable Energy 12, 063101 (2020); https://doi.org/10.1063/5.0010668

Submitted: 13 April 2020 . Accepted: 25 October 2020 . Published Online: 01 December 2020

L. A. Martín, (D) C. A. Popovich, M. C. Damiani, and P. I. Leonardi

COLLECTIONS

F This paper was selected as Featured

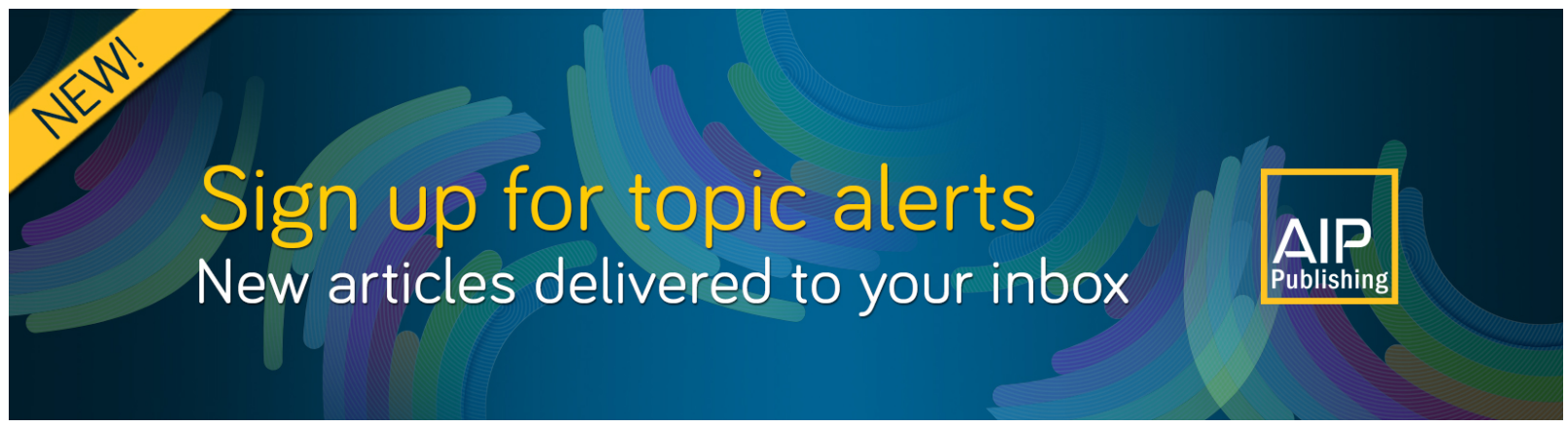




\title{
A practical tool for selecting microalgal species for biodiesel production $\odot$
}

\author{
Cite as: J. Renewable Sustainable Energy 12, 063101 (2020); doi: 10.1063/5.0010668 \\ Submitted: 13 April 2020 . Accepted: 25 October 2020 . \\ Published Online: 1 December 2020

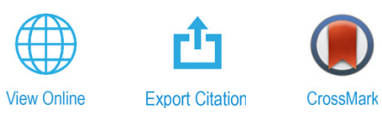

\author{
L. A. Martín, ${ }^{1, a)}$ (D) C. A. Popovich, ${ }^{1,2}$ (D) M. C. Damiani, and P. I. Leonardi?
}

\begin{abstract}
AFFILIATIONS
'Laboratorio de Estudios Básicos y Biotecnológicos en Algas (LEBBA), Centro de Recursos Naturales Renovables de la Zona Semiárida (CERZOS) CONICET-UNS, Camino La Carrindanga, Km 7, 8000, Bahía Blanca. Universidad Nacional del Sur, Departamento de Biología, Bioquímica y Farmacia. San Juan 670, 8000 Bahía Blanca, Argentina

${ }^{2}$ Centro de Emprendedorismo y Desarrollo Territorial Sostenible (CEDETS) CIC-UPSO, Ciudad de Cali 320, Bahía Blanca, Argentina
\end{abstract}

a) Author to whom correspondence should be addressed: lucas.martin@uns.edu.ar. Tel.: 54 (0291) 4861124

\begin{abstract}
In the search for energy sources to replace fossil fuels, microalgae have shown promising characteristics. Their cultures have several advantages over the conventional crops used for commercial biodiesel: they have fast growth rates and a high lipid content and can grow in environments unfit for agriculture. However, relatively few species have so far been studied as biodiesel feedstock. In order to facilitate the search for potentially useful species/strains, in this work, a bioprospecting tool based on biomass and oil production process requirements, triacylglyceride content, and biodiesel properties has been developed. For this purpose, an overall score (OS) was proposed as a tool based on biological, economic, and environmental factors. By applying the OS to nine species, we were able to narrow down the number of species within the diatom group, which are potentially suitable for large-scale biodiesel production. Halamphora coffeaeformis, Navicula cincta, and $N$. gregaria were the species with the highest OS (1.65-1.5). It is expected that this tool will provide a useful contribution to the criteria applied in the selection of microalgal species for large-scale biodiesel production.
\end{abstract}

Published under license by AIP Publishing. https://doi.org/10.1063/5.0010668

\section{INTRODUCTION}

Microalgae are a promising source of energy to replace fossil fuels. Although they have been studied for a variety of processes, including thermochemical processes, anaerobic digestion, and fermentation, ${ }^{1-3}$ most research focuses on the production of biodiesel. ${ }^{4,5}$ Microalgal cultures have several advantages over conventional crops used for commercial biodiesels, including their shorter life cycle and the fact that they can be developed in environments unfit for agriculture, thus avoiding the food-fuel conflict. ${ }^{6}$ However, microalgae cultivation is still not sufficiently cost-effective to compete with conventional biodiesel sources. A number of strategies have recently been adopted to enhance biodiesel production and profitability. Growth and lipid production were enhanced in Tetradesmus obliquus (=Scenedesmus obliquus), for example, by applying blue and red lightemitting diodes during the night, ${ }^{8}$ applying $p$-coumaric acid as the growth regulator, ${ }^{9}$ using growth media supplemented with lipid-free microalgal biomass and waste glycerol, ${ }^{10}$ or employing agar-free seaweed digestate. In Chlorella vulgaris, a pretreatment of inoculum with cold-atmospheric pressure plasma at low doses enhanced both growth and lipid content. ${ }^{11}$ Furthermore, adding a lipid rich residue (fat, oil, and grease) to the microalgae culture could reduce harvest costs and simultaneously improve biodiesel quality. ${ }^{12}$

Despite the advantages of microalgae and the improvements in culture procedures, relatively few species have been studied as biodiesel feedstock. In the search for further species/strains, ${ }^{13}$ the selection of native species is key to ensuring large-scale cultures adapted to local climatic conditions. ${ }^{14}$

Different properties have been evaluated for the purpose of selecting suitable microalgal species for biodiesel production, including the growth rate and lipid content, ${ }^{14,15}$ lipid productivity, ${ }^{16}$ fatty acid (FA) composition, and biodiesel quality. ${ }^{17-19}$ The application of standard methods for determining these properties is often hampered by the volume of material required for analysis and the need for specific equipment, resulting in high costs. ${ }^{18}$ To overcome these drawbacks, various methods have been developed to estimate these properties from the fatty acid (FA) profile of the oils used as biodiesel feedstock. ${ }^{20,21}$ Hoekman et al. ${ }^{22}$ correlated the properties of biodiesels of various feedstocks, finding that the average degree of unsaturation (ADU) of FA was highly correlated with biodiesel properties. These correlations were subsequently applied by several authors to evaluate 
the quality of microalgae biodiesel. ${ }^{17-19,23,24}$ In addition, various tools have been used to evaluate the economic and environmental sustainability of large-scale microalgal processes for biodiesel production: net energy ratio (NER), energy return on investment (EROI), ${ }^{25-27}$ technoeconomic analysis (TEA), ${ }^{28-30}$ and life cycle assessment (LCA). ${ }^{31-33}$

In view of the above, the aim of this study was to apply a tool for selecting microalgal species suitable for biodiesel production based on information relating to biomass and oil production process requirements (PRs), triacylglyceride (TAG) content, and biodiesel properties. The term requirement refers to (1) the resources required for the production of microalgal biomass (water), (2) the stress factors for triggering TAG accumulation (natural stress, artificial nutrient stress, and high light intensities), and (3) the energy required for harvesting and lipid extraction. Based on these criteria, the PRs for biodiesel production of nine microalgal species were classified and scored for the upstream (growing the microalgae and producing the lipids) and downstream (biomass harvesting and lipid extraction) phases. The phases were classified as (1) growth and TAG accumulation (GROWTH + STRESS; GST), (2) harvest (HARVEST; HAR), and (3) lipid extraction (EXTRACTION; EXT). A score was assigned to the TAG content and the biodiesel properties of each species and an overall score (OS) calculated based on the individual score for each species. It is expected that this type of analysis will be useful for selecting suitable microalgae for cost-effective commercial scale biodiesel production.

\section{MATERIALS AND METHODS Strains}

Based on previous research papers identifying potential biodiesel feedstocks, seven species of oleaginous microalgae were selected for application of the tool. Three species were chlorophytes: the freshwater Haematococcus pluvialis isolated from Bahía Blanca (Argentina), ${ }^{34}$ Scenedesmus acutus (PVUW12) collected from a wastewater treatment plant, ${ }^{35}$ and Neochloris oleoabundans (UTEX 1185), another freshwater microalga, acclimated to marine conditions. ${ }^{36}$ The other four species were marine diatoms (Class Bacillariophyceae): Navicula gregaria, ${ }^{37}$ Skeletonema costatum, ${ }^{37}$ Navicula cincta $^{38,39}$ and Halamphora coffeaeformis, ${ }^{24,40}$ which were isolated from the inner zone of Bahía Blanca Estuary ( $\left.38^{\circ} 45^{\prime} \mathrm{S}, 62^{\circ} 22^{\prime} \mathrm{W}\right)$. Stock cultures of these species are maintained at the Laboratorio de Estudios Básicos y Biotecnológicos en Algas (LEBBA), CERZOS-CONICET, Bahía Blanca, Argentina. Scores for biodiesel properties, PR, and TAG were calculated on the basis of data from previous studies on these species.

Additionally, two widely studied species were evaluated: the chlorophyte Chlorella vulgaris $^{22,41,42}$ and the diatom Phaeodactylum tricornutum. ${ }^{20,43-47}$

\section{Culture media}

Haematococcus pluvialis ${ }^{34}$ and Scenedesmus acutus ${ }^{35}$ were grown in Bold's Basal medium (BBM) ${ }^{48}$ prepared with distilled water, which contained macronutrients $\left(\mathrm{NaNO}_{3}: 2.94 \mathrm{mM}, \mathrm{K}_{2} \mathrm{HPO}_{4}\right.$ : $0.43 \mathrm{mM}$, $\mathrm{KH}_{2} \mathrm{PO}_{4}: \quad 1.29 \mathrm{mM}, \mathrm{NaCl}: 0.43 \mathrm{mM}, \quad \mathrm{MgSO} 4: 0.3 \mathrm{mM}, \mathrm{CaCl}_{2}$ : $0.17 \mathrm{mM}$, and $\mathrm{H}_{3} \mathrm{BO}_{3}: 0.18 \mathrm{mM}$ ) and micronutrients. ${ }^{48}$ The medium was autoclaved, and the $\mathrm{pH}$ was adjusted to 7.0. Neochloris oleoabundans $^{36}$ and Navicula cincta $2^{39}$ were grown in SWES (seawater + soil extract + salts) medium, and the remaining diatom species were grown in $\mathrm{f} / 2$ medium $+\mathrm{Si}^{24,37,38,40}$ These media were prepared with aged and filtered $(0.45 \mu \mathrm{m}$ Millipore) seawater from Bahía Blanca Estuary (salinity 30 ) and autoclaved, and the $\mathrm{pH}$ adjusted to $8.0 .^{38}$ The $\mathrm{f} / 2$ medium contained $\mathrm{NaNO}_{3}(0.8 \mathrm{mM}), \mathrm{K}_{2} \mathrm{HPO}_{4} \quad(0.05 \mathrm{mM})$, $\mathrm{Na}_{2} \mathrm{SiO}_{3}(0.24 \mathrm{mM})$, micronutrients, and vitamins. ${ }^{49}$ The SWES medium was enriched with $\mathrm{NaNO}_{3}(1.9 \mathrm{mM}), \mathrm{K}_{2} \mathrm{HPO}_{4}(0.144 \mathrm{mM}), \mathrm{Na}_{2} \mathrm{SiO}_{3}$ $(1.6 \mathrm{mM})$, soil extract, and micronutrient solution. The latter solution was the same as for the $\mathrm{f} / 2$ medium. ${ }^{49}$ Halamphora coffeaformis 2 differed from $H$. coffeaeformis 1 in that the former was grown in $\mathrm{f} / 2$ medium without vitamins. ${ }^{40}$ Detailed media compositions are shown in the supplementary material.

\section{Harvesting}

Navicula gregaria, N. cincta, and H. coffeaeformis form a biofilm at the bottom when mixing and/or aeration has stopped. The supernatant is, then, removed by siphoning, and the biofilm was collected by scraping. ${ }^{24,37-40}$ Chlorella vulgaris was harvested by filtration. ${ }^{42}$ All other species were harvested by centrifugation. ${ }^{34-37,46}$

\section{Biomass and oil production process score}

The first step was to assign a score to each of the nine microalgal species in accordance with the biomass and oil production process requirements (PS) for each of the following phases: (1) growth and TAG accumulation (GST), (2) harvest (HAR), and (3) lipid extraction (EXT) (Fig. 1). A score of 1 was assigned for the positive aspects (e.g., use of seawater for culture, low energy consumption for stress, harvest, and/or lipid extraction). A score of 0 was assigned for negative aspects (e.g., use of freshwater for culture high energy consumption for stress, harvest, and/or lipid extraction). A score of 0.5 indicates species presenting both positive and negative aspects in the same phase. The total score for each species was calculated as the sum of the GST, HAR, and EXT scores, ranging from 0 to 3 . Additive scoring was used instead of multiplication in order to avoid zero values distorting the real value of the score.

\section{Tag score}

The second step was to determine the TAG scores (TS) according to the TAG content of each species (Table I). For this, a threshold value of $20 \%$ dry weight (DW) TAG content was used as this is the lowest acceptable value for microalgae to qualify for biodiesel production purposes. ${ }^{13,43}$ Values greater than $30 \%$ are considered highly productive according to Beal et al. ${ }^{25}$

\section{Biodiesel score}

The third step consisted in calculating the biodiesel score (BS) for each species, determined as the product of the scores for the cetane number $(\mathrm{CN})$, kinematic viscosity $(\mathrm{KV})$, iodine value (IV), higher heating value (HHV), and cold filter plugging point (CFPP), all assigned according to Giordano et al. ${ }^{17}$

The kinematic viscosity, specific gravity (SG), cloud point (CP), CN, $\mathrm{IV}$, and HHV were calculated in relation to ADU (average degree of unsaturation) according to Hoekman et al. ${ }^{22}$ using the following equations:

$$
A D U=\sum M x Y_{i}
$$

where $\mathrm{M}$ is the number of carbon-carbon double bonds in each fatty acid (FA) constituent and Yi is the associated mass fraction, 


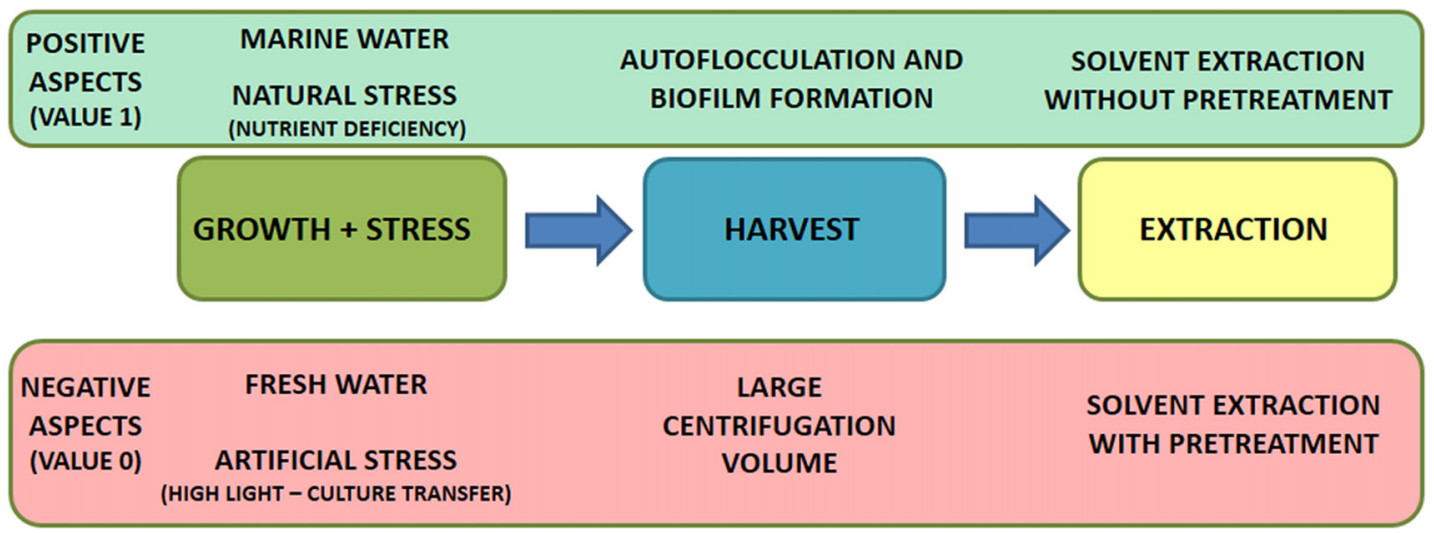

FIG. 1. Block diagram showing the positive and negative aspects considered in assigning process scores.

$$
\begin{gathered}
\mathrm{KV}=-0.6316 x+5.2065, \\
\mathrm{SG}=0.0055 x+0.8726, \\
\mathrm{CP}=-13.356 x+19.994, \\
\mathrm{CN}=-6.6684 x+62.876, \\
\mathrm{IV}=74.373 x+12.71, \\
\mathrm{HHV}=1.7601 x+38.534
\end{gathered}
$$

The cold filter plugging point (CFPP) was estimated as reported by Ramos et al. ${ }^{20}$ using the following equation:

$$
\text { CFPP }=8.9243 . \text { LCSF }-19.325,
$$

where LCSF is the long-chain saturated factor calculated from the composition of saturated FA, according to the following equation:

$$
\begin{aligned}
\mathrm{LCSF}= & C 18(\% \text { wt. }) \cdot \mathrm{MP}_{\mathrm{C} 18}+C 20(\% \text { wt. }) \cdot \mathrm{MP}_{\mathrm{C} 20} \\
& +C 22(\% \text { wt. }) \cdot \mathrm{MP}_{\mathrm{C} 22}+C 24(\% \text { wt. }) \cdot \mathrm{MP}_{\mathrm{C} 24},
\end{aligned}
$$

where MP is the melting point of each FA.

The quality of soybean, palm, and canola oils ${ }^{22}$ used for commercial biodiesel production and of microalgae oils reported in the literature as potentially useful for biodiesel (Chlorella vulgaris and Phaeodactylum tricornutum) was determined and compared.

The scores for CN, KV, HHV, and CFPP were assigned according to Table II, following Giordano et al. ${ }^{17}$

Finally, the BS was calculated as follows:

$$
\mathrm{BS}=\mathrm{CNS} \text {. KVS . CFPPS . HHVS. }
$$

The theoretical range of BS was 0.50 to 1296 . The maximum value corresponds to the oil with the best overall performance according to the EN 14214:2008 standard. ${ }^{17}$

TABLE I. Criteria used to assign TAG scores. DW: dry weight.

\begin{tabular}{lc}
\hline \hline TAG content $(\% D W)$ & TAG score \\
\hline$\leq 20$ & 0 \\
$20-30$ & 0.5 \\
$>30$ & 1 \\
\hline
\end{tabular}

\section{Overall score}

Finally, an overall score (OS) was calculated on the basis of the individual scores for biomass and lipid production processes, TAG content, and biodiesel quality, using the following equation:

TABLE II. Scores assigned to each biodiesel property.

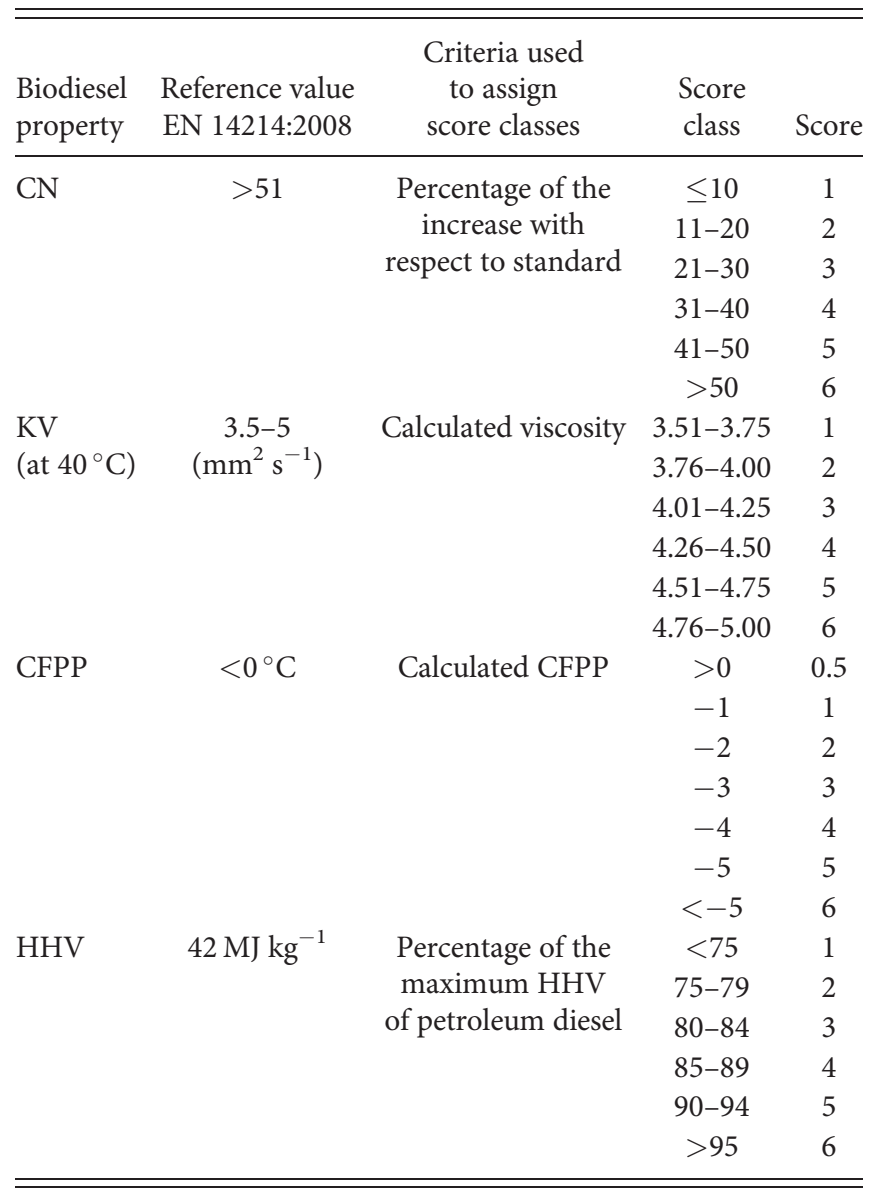




$$
\mathrm{OS}=\frac{\mathrm{PS}+\mathrm{TS}+\left(\frac{\mathrm{BS}}{100}\right)}{3},
$$

where PS = process score, TS = TAG score, and BS = biodiesel score.

The BS was divided by 100 to adapt it to the range of variation in the PS and TS values.

\section{RESULTS AND DISCUSSION \\ Biomass and oil production process score}

The maximum growth rate $(\mu \max )$ and process requirement (PS) scores for each studied microalga are shown in Table III. A high growth rate has been widely used as a selection criterion in the search for viable microalgae for biodiesel production. ${ }^{50}$ However, the measured values vary considerably both among species and strains within the same species, depending on the conditions under which they are measured. Since growing systems can never be exactly the same, ${ }^{51}$ differences can occur even when the measurements are taken under controlled growing conditions. Furthermore, lipid accumulation usually occurs under stress conditions, when growth is low. ${ }^{50}$ For both these reasons, the growth rate has not been included in the PS calculation, and the focus has been placed instead on the species requirements for cultivation and downstream processes related to economic, energetic, and environmental aspects.

For the PS calculation, a value of 1 was assigned to species that use seawater for the GROWTH phase. From an environmental standpoint, an important factor in large-scale cultures is avoidance of water costs through freshwater savings. ${ }^{28,52}$ Furthermore, saline media contribute to a reduction in the contamination risk. ${ }^{14}$ A 0 value was assigned to $H$. pluvialis, C. vulgaris, and $S$. acutus due to freshwater use in culture media (Table III). The successful cultivation of several Chlorella and Scenedesmus species ${ }^{53}$ in wastewater improves the economic and environmental aspects of the GROWTH phase for these species. Another interesting possibility is industrial $\mathrm{CO}_{2}$ utilization, ${ }^{54}$ which has environmental and economic benefits and improves microalgae growth.

For the STRESS phase, a 0 value was assigned to $H$. pluvialis and the use of high light intensity $\left(300 \mu \mathrm{mol} \text { photons } \mathrm{m}^{-2} \mathrm{~s}^{-1}\right)^{34}$ to stress the cells for lipid accumulation requiring greater energy expenditure (Table III). For species where nutrient-limiting stress was applied, the higher operational and energy costs involving in transferring the culture to a nutrient-free medium imply a 0 value for $S$. acutus. In the case of $N$. oleoabundans, a value of 0.5 was assigned due to the use of seawater in the GROWTH phase (Table III). In diatoms, nutrient limitation occurs naturally due to culture ageing, thus avoiding the need to transfer the biomass. A value of 1 was, therefore, assigned to this phase for N. cincta, N. gregaria, S. costatum, H. coffeaeformis, and P. tricornutum (Table III).

For the HAR phase, a value of 1 was assigned to benthic diatom species in view of their capacity to autoflocculate and form biofilms (Table III), thus avoiding the centrifugation of large volumes or the addition of chemical flocculants. Harvesting can represent up to $20 \%-30 \%$ of the culture operating costs ${ }^{52,55}$ and together with biomass production is the main economic investment for scaling up the process. ${ }^{52}$ In this respect, diatoms offer a significant cost benefit, allowing reduced use of water through recycling and also less nutrient input, leading to improved environmental performance and more efficient

TABLE III. Process requirement score (PS): maximum growth rates and scores assigned for each phase and final PS for the nine microalgal species.

\begin{tabular}{|c|c|c|c|c|c|c|c|c|}
\hline & \multicolumn{3}{|c|}{ Growth + stress } & \multicolumn{2}{|l|}{ Harvest } & \multicolumn{2}{|l|}{ Extraction } & \multirow[b]{2}{*}{$\begin{array}{c}\text { Process } \\
\text { score }\end{array}$} \\
\hline & $\begin{array}{l}\text { Maximum growth } \\
\text { rate }\left(\mu \max , \mathrm{d}^{-1}\right)\end{array}$ & Requirement & Score & Requirement & Score & Requirement & Score & \\
\hline H. pluvialis & $0.55^{34}$ & $\begin{array}{l}\text { Freshwater use }+ \text { high } \\
\text { light stress }\end{array}$ & 0 & $\begin{array}{l}\text { Autoflocculation but } \\
\text { not biofilm }\end{array}$ & 0.5 & $\begin{array}{l}\text { Resistant cell wall- } \\
\text { pretreatment } \\
\text { required }^{34}\end{array}$ & 0 & 0.5 \\
\hline S. acutus & $0.68^{35, a}$ & $\begin{array}{l}\text { Freshwater use }+ \text { cul- } \\
\quad \text { ture transfer }^{35}\end{array}$ & 0 & Centrifugation $^{35}$ & 0 & $\begin{array}{l}\text { Not pretreatment } \\
\text { required }^{35}\end{array}$ & 1 & 1 \\
\hline N. oleoabundans & $0.51^{36, a}$ & $\begin{array}{c}\text { Seawater use }+ \text { culture } \\
\text { transfer }^{36}\end{array}$ & 0.5 & Centrifugation $^{36}$ & 0 & $\begin{array}{l}\text { Not pretreatment } \\
\text { required }^{36}\end{array}$ & 1 & 1.5 \\
\hline $\begin{array}{l}\text { N. cincta } 1 \\
\text { N. cincta } 2\end{array}$ & $\begin{array}{c}0.98^{38, a} \\
0.47^{39}\end{array}$ & $\begin{array}{l}\text { Seawater use }+ \text { natural } \\
\text { stress }^{24,37-40}\end{array}$ & 1 & $\begin{array}{c}\text { Autoflocculation }+ \\
\text { biofilm formation }{ }^{37-39}\end{array}$ & 1 & $\begin{array}{l}\text { Not pretreatment } \\
\text { required }\end{array}$ & 1 & 3 \\
\hline N. gregaria & $0.55^{37, \mathrm{a}}$ & & 1 & & 1 & & 1 & 3 \\
\hline S. costatum & $0.97^{37, a}$ & & 1 & $\begin{array}{c}\text { Autoflocculation but } \\
\text { not biofilm }\end{array}$ & 0.5 & & 1 & 2.5 \\
\hline H. coffeaeformis 1 & $0.48^{24, a}$ & & 1 & Autoflocculation + & 1 & & 1 & 3 \\
\hline H. coffeaeformis 2 & $0.42^{40}$ & & & biofilm formation ${ }^{24,40}$ & & & & \\
\hline C. vulgaris & $0.16^{42}$ & Freshwater use ${ }^{42}$ & 0 & $\begin{array}{l}\text { Flocculant use }+ \\
\quad \text { filtration }\end{array}$ & 0 & $\begin{array}{l}\text { Resistant cell wall- } \\
\text { pretreatment } \\
\text { required }^{42}\end{array}$ & 0 & 0 \\
\hline P. tricornutum & $0.33^{45}$ & $\begin{array}{c}\text { Seawater use }+ \text { natural } \\
\text { stress }\end{array}$ & 1 & $\begin{array}{l}\text { Flocculant use }+ \\
\text { centrifugation }\end{array}$ & 0 & $\begin{array}{l}\text { Not pretreatment } \\
\text { required }^{46}\end{array}$ & 1 & 2 \\
\hline
\end{tabular}

${ }^{\mathrm{a}}$ Calculated from $k\left(\right.$ div. $\left.\mathrm{d}^{-1}\right)$. 
TABLE IV. TAG content and score (TS) for the nine microalgal species.

\begin{tabular}{lcc}
\hline \hline & TAG content (\%DW) & TAG score \\
\hline H. pluvialis & $19.8^{34}$ & 0 \\
S. acutus & $25.6^{35}$ & 0.5 \\
N. oleoabundans & $20.8^{36}$ & 0.5 \\
N.cincta1 & $25.9^{38, \mathrm{a}}$ & 0.5 \\
N. cincta2 & $30.4^{39, \mathrm{a}}$ & 1 \\
N. gregaria & $18.2^{37, \mathrm{~b}}$ & 0 \\
S. costatum & $14.3^{37, \mathrm{~b}}$ & 0 \\
H. coffeaeformis 1 & $26.2^{24, \mathrm{a}}$ & 0.5 \\
H. coffeaeformis 2 & $22.0^{40, \mathrm{a}}$ & 0.5 \\
C. vulgaris & $23.5^{41}$ & 0.5 \\
$P$. tricornutum & $\approx 25^{47}$ & 0.5 \\
\hline \hline
\end{tabular}

${ }^{\mathrm{a}} \% \mathrm{DW}$ was calculated from $\%$ ash free dry weight.

$\mathrm{b}_{\% \mathrm{DW}}$ was calculated from TAG percentage with respect to total lipids.

control of nutrient discharge. ${ }^{31} \mathrm{~A}$ value of 0 was assigned to planktonic species requiring flocculants and centrifugation or filtration for harvesting (Table III). Although $H$. pluvialis is also a planktonic species, the TAG-rich cysts in the life-cycle stage decant naturally. However, since they do not form a biofilm, the settled cells must be centrifuged to extract the remaining water. ${ }^{34}$ Skeletonema costatum is also a planktonic microalga but with a demonstrated ability to autoflocculate. ${ }^{56}$ As with $H$. pluvialis, decanting in the absence of biofilm formation requires the excess water to be removed by centrifugation. ${ }^{34,37}$ For this reason, a value of 0.5 was assigned to both species for the HAR phase (Table III). For the EXT phase, pretreatment to break the cell wall was required only in the cases of $H$. pluvialis and $C$. vulgaris, for which a 0 value was assigned owing to the extra energy required. Cell disruption of $H$. pluvialis using a bead mill takes up more than $30 \%$ of the total process energy. ${ }^{57}$

Table IV shows the TAG score for each studied microalga. Value 1 was assigned to $N$. cincta2 since its TAG content was greater than $30 \%$ of dry weight (\%DW). Value 0 was given to species with TAG contents lower than $20 \%$ DW. Species with a TAG content between 20 and $30(\% \mathrm{DW})$ were given a value of 0.5 .

\section{Biodiesel score}

Table V shows the biodiesel properties and the BS calculated for each microalga. For comparative purposes, the BS for the commercial biodiesel feedstock palm, soybean, and canola was also calculated. Diatoms presented the highest BS values, equaling or exceeding those of soybean, palm, and canola (Table V). Skeletonema costatum was the species with the highest BS (180), followed by N. gregaria (150) and $H$.

TABLE V. Biodiesel properties calculated from the TAG fatty acid composition of microalgae and limits established by the United States (ASTM D6751-08) and Europe (EN 14214) standards. HHV: higher heating value and CFPP: cold filter plugging point.

\begin{tabular}{|c|c|c|c|c|c|c|c|c|}
\hline & $\begin{array}{c}\text { Kinematic } \\
\text { viscosity } \\
\left(40^{\circ} \mathrm{C} \mathrm{mm}^{2} \mathrm{~s}^{-1}\right)\end{array}$ & $\begin{array}{l}\text { Specific } \\
\text { gravity } \\
\left(\mathrm{kg} \mathrm{l}^{-1}\right)\end{array}$ & $\begin{array}{c}\text { Iodine } \\
\text { value } \\
\left(\mathrm{g} \mathrm{I}_{2} / 100 \mathrm{~g}\right)\end{array}$ & $\begin{array}{c}\mathrm{HHV} \\
\left(\mathrm{MJ} \mathrm{kg}^{-1}\right)\end{array}$ & $\begin{array}{l}\text { Cetane } \\
\text { number }\end{array}$ & $\begin{array}{l}\text { Cloud } \\
\text { point } \\
\left({ }^{\circ} \mathrm{C}\right)\end{array}$ & $\begin{array}{l}\text { CFPP } \\
\left({ }^{\circ} \mathrm{C}\right)\end{array}$ & $\begin{array}{c}\text { Biodiesel } \\
\text { score }\end{array}$ \\
\hline H. pluvialis & 4.427 & 0.879 & 104.479 & 40.706 & 54.648 & 3.514 & 4.280 & 12 \\
\hline S. acutus & 4.402 & 0.880 & 107.476 & 40.777 & 54.379 & 2.976 & -3.062 & 96 \\
\hline N. oleoabundans & 4.577 & 0.878 & 86.793 & 40.287 & 56.234 & 6.690 & -0.809 & 30 \\
\hline N. cincta 1 & 4.194 & 0.881 & 131.900 & 41.355 & 52.189 & -1.410 & -8.836 & 108 \\
\hline N. cincta2 & 4.414 & 0.880 & 106.056 & 40.743 & 54.506 & 3.231 & -3.869 & 96 \\
\hline N. gregaria & 4.526 & 0.879 & 92.854 & 40.431 & 55.690 & 5.602 & -4.903 & 150 \\
\hline S. costatum & 4.619 & 0.878 & 81.877 & 40.171 & 56.674 & 7.573 & -2.333 & 180 \\
\hline H. coffeaeformis 1 & 4.375 & 0.880 & 110.560 & 40.850 & 54.102 & 2.422 & -5.570 & 144 \\
\hline H. coffeaeformis 2 & 4.042 & 0.883 & 149.788 & 41.778 & 50.585 & -4.623 & -4.205 & 90 \\
\hline C. vulgaris & 4.152 & 0.882 & 136.929 & 41.474 & 51.738 & -2.313 & -2.900 & 36 \\
\hline P. tricornutum ${ }^{\mathrm{b}}$ & 4.311 & 0.880 & 118.171 & 41.030 & 53.420 & 1.055 & -8.843 & 144 \\
\hline Soybean $^{c}$ & 4.264 & 0.881 & 123.675 & 41.160 & 52.927 & 0.067 & -6.706 & 144 \\
\hline Palm & 4.818 & 0.876 & 58.449 & 39.616 & 58.775 & 11.780 & 5.515 & 30 \\
\hline Canola $^{e}$ & 4.358 & 0.880 & 112.667 & 40.900 & 53.914 & 2.044 & -7.146 & 144 \\
\hline US (ASTM D6751-08) & $1.9-6.0$ & $0.85-0.90$ & $\ldots$ & $\ldots$ & $>47$ & Report & $\ldots$ & \\
\hline Europe (EN 14214) & $3.5-5.0$ & $\ldots$ & $<120$ & $\ldots$ & $>51$ & $\ldots$ & $\begin{array}{l}\text { depends upon the } \\
\text { location and time } \\
\text { of year }\end{array}$ & \\
\hline
\end{tabular}

${ }^{a}$ Values calculated from the FA composition of the oils reported in the literature for C. vulgaris. ${ }^{22}$

${ }^{b}$ Values calculated from the FA composition of the oils reported in the literature for P. tricornutum. ${ }^{44}$

${ }^{c}$ Values calculated from the FA composition of the oils reported in the literature for soybean. ${ }^{22}$

${ }^{\mathrm{d}}$ Values calculated from the FA composition of the oils reported in the literature for palm. ${ }^{22}$

${ }^{\mathrm{e}}$ Values calculated from the FA composition of the oils reported in the literature for canola. ${ }^{22}$ 
coffeaeformis 1 (144). The latter presented the same score as P. tricornutum, soybean, and canola.

In all cases, the kinematic viscosity, specific gravity, and cetane number presented values in accordance with the American (ASTM D6751-08) and European (EN 14214) standards. Navicula cincta1, $H$. coffeaeformis2, C. vulgaris, and soybean biodiesel exceeded the allowed maximum iodine value (IV) of $120 \mathrm{~g} \mathrm{I}_{2} / 100 \mathrm{~g}$. This parameter is used to estimate the degree of unsaturation. ${ }^{58}$ High IV values indicate the polymerization of glycerides, resulting in deposit formation in the engine. ${ }^{21,58,59}$ This effect increases with larger numbers of double bonds in the FA chain, rather than with the degree of general unsaturation. $^{21}$ The eicosapentaenoic acid (EPA, C20:5) content in diatoms impacts this property, whereas in C. vulgaris and soybean, the high content of linoleic acid (C18:2n-6) could be the main factor affecting the IV.

One of the main advantages of biodiesel derived from diatom oil is its cold filter plugging point (CFPP) values, ranging between -2 and $-9^{\circ} \mathrm{C}$. Desirable low values for cold flow properties (cloud point and CFPP) are associated with a high degree of unsaturation, which is also related to poor oxidative stability. ${ }^{22,60}$ However, the relationship between oxidative stability and unsaturation is not always direct. ${ }^{22,60}$ For example, no oxidative stability problems have been reported in biodiesel derived from camelina oil, despite the latter having almost $35 \%$ of tri-unsaturated FA. ${ }^{22}$ This could be due to the presence of natural antioxidants. ${ }^{58}$ In the case of diatoms, one of the main pigments, fucoxanthin, ${ }^{45}$ has been shown to have antioxidant activity. ${ }^{6}$

\section{OVERALL EVALUATION}

The overall score (OS) calculated for each of the nine microalga species is shown in Fig. 2. Diatoms presented a higher OS than chlorophytes, and the best-ranked diatom species were the benthic diatoms H. coffeaeformis, Navicula cincta, and N. gregaria (1.65-1.5). Their abilities to autoflocculate and generate a biofilm significantly reduced harvest costs, which can represent up to $30 \%$ of the process costs. ${ }^{52,55}$ Skeletonema costatum and P. tricornutum show high BS values but with minor PS values. Since these species have no benthic habits, they do not form biofilms and must be centrifuged for harvesting. Furthermore, their TAG values are lower than 30\%. ${ }^{37,47}$

All chlorophytes showed lower values in both the BS and PS. The worst performing species in this analysis in terms of biodiesel production is $H$. pluvialis, which has the lowest BS value, mainly due to

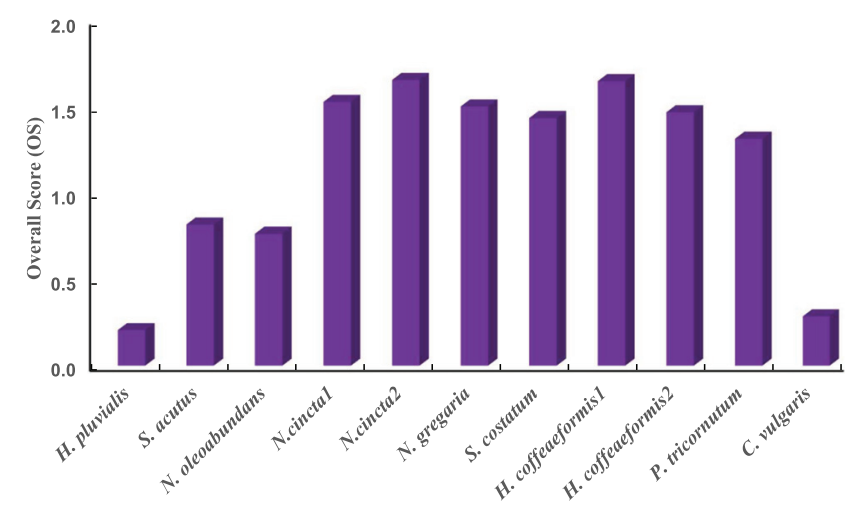

FIG. 2. Overall score calculated for the nine microalgal species. inadequate values in cold flow properties, determined by its high PUFA content. Compared to chlorophytes, many diatom species have favorable characteristics for sustainable biofuel production and are robustly resistant to extreme environmental conditions; ${ }^{51,62}$, however, they have failed as yet to generate a significant degree of scientific interest in the bioenergy field. ${ }^{63}$ The findings of this paper show that diatoms should be at the forefront of bioprospecting efforts for biodiesel production.

\section{CONCLUSIONS}

This study describes a practical tool for selecting microalgal species for biodiesel production based on the biological, economic, and environmental aspects. An overall score standardizes criteria for potential large-scale cultures, covering biomass and oil production requirements, the TAG content, and biodiesel quality. The native benthic diatoms $H$. coffeaeformis, Navicula cincta, and N. gregaria appear to be promising species for biodiesel production. This tool provides a useful criterion for selecting suitable microalgal species for commercial biodiesel production.

\section{SUPPLEMENTARY MATERIAL}

See the supplementary material for a complete culture media composition.

\section{ACKNOWLEDGMENTS}

Funds were provided by the Consejo Nacional de Investigaciones Científicas y Técnicas de la República Argentina (CONICET) (No. PIP 112-2015 01-00510), the Agencia Nacional de Promoción Científica y Tecnológica (No. BID PICT 2015-0800), and the Universidad Nacional del Sur (No. PGI 24/B246). Technical assistance by Jorge Oyola is acknowledged. L.A.M. and P.I.L. are research members of CONICET. C.A.P. is a research member of Comisión de Investigaciones Científicas de la Provincia de Buenos Aires (CIC).

\section{DATA AVAILABILITY}

The data that support the findings of this study are available from the corresponding author upon reasonable request.

\section{REFERENCES}

${ }^{7}$ N. R. Moheimani, D. Parlevliet, M. P. McHenry, P. A. Bahri, and K. de Boer, in Biomass Biofuels from Microalgae, edited by N. Moheimani, M. P. Mchenry, K. de Boer, and P. A. Bahri (Springer, Cham, 2015), pp. 1-18.

${ }^{2}$ S. V. Vassilev and C. G. Vassileva, Fuel 181, 1 (2016).

${ }^{3}$ A. de L. Marques, O. de Q. F. Araújo, and M. C. Cammarota, Biotechnol. Lett. 41, 193 (2019).

${ }^{4}$ E. C. Odjadjare, T. Mutanda, and A. O. Olaniran, Crit. Rev. Biotechnol. 37, 37 (2017).

${ }^{5}$ R. Bhagea, V. Bhoyroo, and D. Puchooa, Microbiol. Res. (Pavia) 10, 7936 (2019).

${ }^{6}$ S. T. L. Harrison, C. Richardson, and M. J. Griffiths, in Biotechnoligical Applications Of Microalgae: Biodiesel and Value Added Products, edited by F. Bux (CRC Press, 2013), pp. 113-136.

${ }^{7}$ A. E. F. Abomohra and A. W. Almutairi, Bioresour. Technol. 317, 124027 (2020).

${ }^{8}$ A. E. F. Abomohra, H. Shang, M. El-Sheekh, H. Eladel, R. Ebaid, S. Wang, and Q. Wang, Bioresour. Technol. 288, 121514 (2019).

${ }^{9}$ S. Esakkimuthu, V. Krishnamurthy, S. Wang, X. Hu, S. K, and A. E. F. Abomohra, Renewable Energy 157, 368 (2020). 
${ }^{10}$ A. E. F. Abomohra, H. Eladel, M. El-Esawi, S. Wang, Q. Wang, Z. He, Y. Feng, H. Shang, and D. Hanelt, Bioresour. Technol. 249, 992 (2018).

"J. Q. M. Almarashi, S. E. El-Zohary, M. A. Ellabban, and A. E. F. Abomohra, Energy Convers. Manage. 204, 112314 (2020).

${ }^{12}$ A. E. F. Abomohra, M. Elsayed, S. Esakkimuthu, M. El-Sheekh, and D. Hanelt, Prog. Energy Combust. Sci. 81, 100868 (2020).

${ }^{13}$ Q. Hu, M. Sommerfeld, E. Jarvis, M. Ghirardi, M. Posewitz, M. Seibert, and A. Darzins, Plant J. 54, 621 (2008).

${ }^{14}$ M. J. Griffiths and S. T. L. Harrison, J. Appl. Phycol. 21, 493 (2009).

${ }^{15}$ M. K. Pandey, C. N. Dasgupta, S. Mishra, M. Srivastava, V. K. Gupta, M. R. Suseela, and P. W. Ramteke, Appl. Microbiol. Biotechnol. 103, 5447 (2019).

${ }^{16}$ M. J. Griffiths, R. P. van Hille, and S. T. L. Harrison, J. Appl. Phycol. 24, 989 (2012).

${ }^{17}$ M. Giordano, M. Palmucci, and A. Norici, J. Appl. Phycol. 27, 1401 (2015).

${ }^{18}$ C. D. Calixto, J. K. da Silva Santana, V. P. Tibúrcio, L. de F. B. L. de Pontes, C. F. da Costa Sassi, M. M. da Conceição, and R. Sassi, Renewable Energy 115, 1144 (2018).

${ }^{19}$ M. Song, H. Pei, W. Hu, and G. Ma, Bioresour. Technol. 141, 245 (2013).

${ }^{20}$ M. J. Ramos, C. M. Fernández, A. Casas, L. Rodríguez, and Á. Pérez, Bioresour. Technol. 100, 261 (2009).

${ }^{21}$ E. Francisco, D. D. B. Neves, E. Jacob-Lopez, T. T. T. Franco, É. C. Francisco, D. D. B. Neves, E. Jacob-Lopes, and T. T. T. Franco, J. Chem. Technol. Biotechnol. 85, 395 (2010).

${ }^{22}$ S. K. Hoekman, A. Broch, C. Robbins, E. Ceniceros, and M. Natarajan, Renewable Sustainable Energy Rev. 16, 143 (2012).

${ }^{23}$ Q. Hu, W. Xiang, S. Dai, T. Li, F. Yang, Q. Jia, G. Wang, and H. Wu, Bioresour. Technol. 192, 157 (2015).

${ }^{24}$ L. A. Martín, C. A. Popovich, A. M. Martinez, M. C. Damiani, and P. I. Leonardi, Renewable Energy 92, 127 (2016).

${ }^{25}$ C. M. Beal, R. E. Hebner, M. E. Webber, R. S. Ruoff, A. F. Seibert, and C. W. King, Energies 5, 1943 (2012).

${ }^{26} \mathrm{R}$. Slade and A. Bauen, Biomass Bioenergy 53, 29 (2013).

${ }^{27}$ M. R. Tredici, N. Bassi, M. Prussi, N. Biondi, L. Rodolfi, G. C. Zittelli, and G. Sampietro, Appl. Energy 154, 1103 (2015).

${ }^{28}$ C. M. Beal, L. N. Gerber, D. L. Sills, M. E. Huntley, S. C. Machesky, M. J. Walsh, J. W. Tester, I. Archibald, J. Granados, and C. H. Greene, Algal Res. 10, 266 (2015).

${ }^{29}$ A. K. Kumar, S. Sharma, G. Dixit, E. Shah, and A. Patel, Renewable Energy $145,1620(2020)$.

${ }^{30}$ T. M. Louw, M. J. Griffiths, S. Jones, and S. T. L. Harrison, in Algae Biotechnology: Products and Processes (Springer, 2016), pp. 111-141.

${ }^{31}$ J. Hou, P. Zhang, X. Yuan, and Y. Zheng, Renewable Sustainable Energy Rev. 15, 5081 (2011).

${ }^{32}$ M. L. N. M. Carneiro, F. Pradelle, S. L. Braga, M. S. P. Gomes, A. R. F. A. Martins, F. Turkovics, and R. N. C. Pradelle, Renewable Sustainable Energy Rev. 73, 632 (2017).

33B. Adhikari and J. Pellegrino, J. Renewable Sustainable Energy 7, 043136 (2015).

${ }^{34}$ M. C. Damiani, C. A. Popovich, D. Constenla, and P. I. Leonardi, Bioresour. Technol. 101, 3801 (2010).

${ }^{35}$ M. C. Damiani, C. A. Popovich, D. Constenla, A. M. Martínez, E. Doria, P. Longoni, R. Cella, E. Nielsen, and P. I. Leonardi, J. Appl. Phycol. 26, 1423 (2014).

${ }^{36}$ C. A. Popovich, C. Damiani, D. Constenla, A. M. Martínez, H. Freije, M. Giovanardi, S. Pancaldi, and P. I. Leonardi, Bioresour. Technol. 114, 287 (2012).
${ }^{37}$ C. A. Popovich, C. Damiani, D. Constenla, and P. I. Leonardi, J. Appl. Phycol. 24, 1 (2012)

${ }^{38}$ G. B. Bielsa, C. A. Popovich, M. C. Rodríguez, A. M. Martínez, L. A. Martín, M. C. Matulewicz, and P. I. Leonardi, Algal Res. 15, 120 (2016).

${ }^{39}$ C. A. Popovich, M. Pistonesi, P. Hegel, D. Constenla, L. A. Martín, G. Barnech Bielsa, M. C. Damiani, and P. I. Leonardi, Algal Res. 39, 101438 (2019).

${ }^{40}$ L. A. Martín, C. A. Popovich, A. M. Martínez, P. G. Scodelaro Bilbao, M. C. Damiani, and P. I. Leonardi, Renewable Energy 118, 984 (2018).

${ }^{41}$ E. J. Lohman, R. D. Gardner, T. Pedersen, B. M. Peyton, K. E. Cooksey, and R. Gerlach, Biotechnol. Biofuels 8, 82 (2015).

${ }^{42}$ A. K. Sharma, P. K. Sahoo, S. Singhal, and G. Joshi, Bioresour. Technol. 216, 793 (2016).

${ }^{43}$ T. Obata, A. R. Fernie, and A. Nunes-Nesi, Metabolites 3, 325 (2013).

${ }^{44}$ D. L. Alonso, B. El-Hassan, J. M. Fernandez-Sevilla, J. Rodriguez-Ruiz, E. Molina Grima, J. Rodriguez-Ruiza, E. Molina Grima, J. M. FernándezSevilla, J. Rodríguez-Ruiza, and E. Molina Grima, Phytochemistry 54, 461 (2000).

${ }^{45} \mathrm{H}$. Wu, T. Li, G. Wang, S. Dai, H. He, and W. Xiang, Chin. J. Oceanol. Limnol. 34, 391 (2016).

${ }^{46}$ M. Branco-Vieira, S. S. Martin, C. Agurto, M. A. Dos Santos, M. A. V. Freitas, T. M. Mata, A. A. Martins, N. S. Caetano, S. San Martin, C. Agurto, M. Santos, M. A. V. Freitas, T. M. Mata, A. A. Martins, and N. S. Caetano, Energies 11(1), 54 (2018).

${ }^{47}$ I. M. Remmers, D. E. Martens, R. H. Wijffels, and P. P. Lamers, PLoS One 12, e0175630 (2017).

${ }^{48} \mathrm{H}$. W. Nichols, in Handb. Phycol. Methods. Cult. Methods Meas., edited by J. R. Stein (Cambridge University Press, London, 1973), pp. 7-24.

49. L. McLachlan, in Handb. Phycol. Methods Cult. Methods Growth Meas., edited by J. R. Stein (Cambridge University Press, Cambridge, 1973), pp. $26-47$.

${ }^{50}$ X. Deng, Y. Li, and X. Fei, Afr. J. Microbiol. Res. 3, 1008 (2009).

${ }^{51}$ M. Hildebrand, A. K. Davis, S. R. Smith, J. C. Traller, and R. Abbriano, Biofuels 3, 221 (2012)

${ }^{52}$ J. N. Rogers, J. N. Rosenberg, B. J. Guzman, V. H. Oh, L. E. Mimbela, A. Ghassemi, M. J. Betenbaugh, G. A. Oyler, and M. D. Donohue, Algal Res. 4, 76 (2014).

${ }^{53}$ S. Lage, Z. Gojkovic, C. Funk, and F. G. Gentili, Energies 11, 664 (2018).

${ }^{54}$ M. Lakshmikandan, A. G. Murugesan, S. Wang, A. E. F. Abomohra, P. A. Jovita, and S. Kiruthiga, J. Clean. Prod. 247, 119398 (2020).

${ }^{55}$ E. Molina Grima, E. H. Belarbi, F. G. Acién Fernández, A. R. Medina, and Y. Chisti, Biotechnol. Adv. 20, 491 (2003).

${ }^{56}$ P. M. Schenk, S. R. Thomas-Hall, E. Stephens, U. C. Marx, J. H. Mussgnug, C. Posten, O. Kruse, and B. Hankamer, BioEnergy Res. 1, 20 (2008).

${ }^{57}$ L. F. Razon and R. R. Tan, Appl. Energy 88, 3507 (2011).

${ }^{58}$ E. G. Giakoumis, Renewable Energy 50, 858 (2013).

${ }^{59}$ S. K. Mandotra, P. Kumar, M. R. Suseela, and P. W. Ramteke, Bioresour. Technol. 156, 42 (2014).

${ }^{60}$ G. R. Stansell, V. M. Gray, and S. D. Sym, J. Appl. Phycol. 24, 791 (2012).

${ }^{61}$ S. Xia, K. Wang, L. Wan, A. Li, Q. Hu, and C. Zhang, Mar. Drugs 11, 2667 (2013).

${ }^{62}$ O. Levitan, J. Dinamarca, G. Hochman, and P. G. Falkowski, Trends Biotechnol. 32, 117 (2014).

${ }^{63}$ F. J. Fields and J. P. Kociolek, J. Appl. Phycol 27, 2209 (2015). 